\title{
Using Crossword Puzzle to increase Students' Vocabularies for Writing Skill in Descriptive Text
}

\author{
Putu Ngurah Rusmawan \\ STKIP PGRI Pasuruan, Indonesia \\ afatah72@gmail.com
}

\begin{abstract}
The purpose of the study is to know using media puzzle improve the students writing descriptive text for the second graders at SMP Negeri 5 Pasuruan. The researcher used a classroom action research. This research was conducted on April 05 2017 to May 06 ${ }^{\text {th }} 2017$. To get the information about the implementation of the crossword puzzle in descriptive text for writing skill, the researcher used interview, observation, questionnaire, test and documentation. The result of the test at the end of the first cycle showed that 26 students got under 76 . It was not successful because it was still below criteria of success which required at least 76 as minimum score. In the cycle two, there were 27 students who got at least or more 76 . It can be concluded that all students got the criteria of success, which required at least 76 as the minimum score. Finally, it can be concluded that the result of this research showed that using crossword puzzle can improve the students' writing skill in teaching learning English. It can help the students to memorize the material easily and it can give positive effect for the students
\end{abstract}

Keywords: Writing, Descriptive, Crossword Puzzle.

\section{INTRODUCTION}

Writing skill in second language needs hard thinking in producing words, sentences, and paragraphs. Moreover, to write well the students should to know grammatical structure, vocabulary, and the sign or symbol to make a good sentences. Harmer (2007) says that the writing process is more complex. Writing takes more time, namely time to brainstorm ideas, time to draft a piece of writing and then review it and edit in various ways before, re-drafting, re-editing, and so on. The writing habit should be stimulated among students and give them understanding about writing. By mastering writing skill, it brings many advantages for them. Through writing they can share thoughts, information, and ideas. They must be able to communicate and connect

\author{
ENGLISH FRANCA : Academic Journal of English Language and Education \\ Vol. 2, No. 1, 2018, STAIN Curup \\ P-ISSN 2580-3670, E-ISSN 2580-3689
}


among people all over the world. Writing can help them to receive much information and learn new things that are important to develop their skill. They can write smoothly what they want, the students can get enjoyable from writing; they can write what they want to write related with letter, diary, and advertisement.

Rahmawati (2013) states that descriptive text is a text which says what a person or a thing is like and to describe and reveal a perticular person, place, or thing. The teacher should have kind of ways to make their students understand descriptive text. Students have to achieve the target in Standard and Basic Competence based on Curriculum 2013 syllabus. In addition, students have to understand the generic stucture, social function and language features of descriptive text.

The crossword puzzle game offers a challenge that will motivate the students to try to fulfill the puzzle (Widaningsih, 2009). Moreover, Dewi (2010:18) also states that crossword puzzle can be used in teaching learning process to increase the students' interest, to motivate students in learning English, and then the students may feel more relax. It has been beneficially used in teaching learning process. It gives much opportunity for the students to spell, and pronounce the vocabulary. Beside, the crossword puzzle is a kind of games that will make the teaching learning process more attractive than before. The students will feel fun, relaxed and enjoyable, and they will memorize the vocabulary in different way, that is by rewriting them. A crossword is word game which is played on a grid puzzle. There are clues given to the different word that are required to complex the grid. The normal crossword puzzles have vertical and horizontal clues. Thus, in this research, the researcher chose crossword puzzle to improve the students' writing skill to construct their writing activity, especially in constructing decsriptive text.

Based on data from interview English teacher of SMP Negeri 5 Pasuruan on October 2016. The students have low motivation to learn English because the students were difficult to understand English lesson especially writing. The students were difficult to express the idea or thought in written form, because they do not know the English word of a certain vocabulary. The teacher only used monotonous teaching media in teaching English such as using a blackboard. So, there are many causes which make the students difficult to understand English lesson especially writing. 
There are many ways to make teaching writing more effective, interesting and help student in write descriptive text well. One of the ways that can be used is by using crossword puzzle.

In this research, the researcher chooses the eight grade students of SMP Negeri 5 Pasuruan because most of eight graders have the problem in how they using crossword puzzle is the appropriate way for the students to choose the word in composing a sentence. By using crossword puzzle they can directly produce an idea to arrange that word. The students will get some difficulties to choose the word if teacher does not use an teaching aid like crossword puzzle.

From the explanation above, the reseacher intends in using crossword puzzle to teach writing in the eight grade of SMP Negeri 5 Pasuruan because it can help to improve the students writing descriptive skill. Based on the explanation above, the researcher focuses on teaching students in writing skills by using crossword puzzle. Problem of the study is "How can crossword puzzle improve students' writing descriptive text at the second grade of SMP Negeri 5 Pasuruan?"

\section{LITERATURE REVIEW}

Teaching writing in English is important for students, especially in non-English speaking countries. In general teaching writing in English has two major approaches: process and genre/product. Process approach is concerned with phases in writing process, while genre approach requires learners to examine texts they are going to write before they start their own writing (Harmer, 2007). The basic competence of writing is the second semester in getting the meaning of oral and written descriptive text by crossword puzzle to communicate English in their daily life context (based on the school-based curriculum).Teacher should explain the objectives of the learning the students should achieve through the game.

The teacher should explain the rules of the game clearly, teacher should integrate the game into the lesson, students show equal participation, teacher should stop the game before students get bored of it, teacher should never interrupt the game which is following smoothly, and teacher should set a limit of time.

Siti (2013) Crossword puzzle can be done in a group or individually. The teacher gives a copy of the 'crossword puzzle' and explains the rules, such as students have to fill the columns as soon as possible, and who will get the first is the winner and get the good point 
from the teacher. In pair work group, the winner is the first complete the columns. The use of crossword puzzle in teaching vocabulary is one of the alternative techniques to help the students construct and improve their vocabulary enlargement. Suyanto (2008:117) says that game is an activity which is done based on the certain rule. Suyanto states that, according to some expert, language game which is communicative has six characteristics. Those characteristics namely: game must be interactive, the player must be clear, the player must be involved actively, the player get specific rules in the game.

Other important skills required for completing these puzzles include making inferences, evaluating choices, and drawing conclusions as explained by Davis (2009). Furthermore, crossword puzzle is helping the students to develop and enrich their stock of vocabulary and it helps the teacher to achieve the goals in studying English.

A crossword is a word puzzles that normally takes the form of a square or a rectangular grid of white and black shaded squares (Davis, 2009). The goal is to fill the white squares with letters, forming words and phrases, by solving clues which lead to the answers. In language that are written left-to-right, the answer words and phrases are placed in the grid form left to right and from top to bottom. Crossword puzzle can be used as a tehnique in teaching vocabulary to the Junior High School students. Every crossword puzzle uses clues to find out the answers, it could ne down and across.

There were some previous studies which have similar background of problems and related to this research: Solikha, (2014) also conducts her research entitled "Using Crossword Puzzle Game to improve the Students' writing skill in descriptive skill in descriptive text at the first grade of SMP Islam Mamba'ul Ulum Al Mubarok Jabon Sidoarjo" this research investigates the using crossword puzzle game to improving Students' writing skill. In general, the finding of the research shows that the using crossword puzzle game to improving students' writing skill was improved; it was shown by the score of the students when they have done the test.

Nikmatul Huda, (2015) apply crossword puzzle game in her research entitled"Using Crossword Puzzle Game to Improve the Students' Writing Skill in Descriptive Text At the first Grade of MTs Darun Nur Rukem Pohjentrek Pasuruan". The purpose of the study is to improve the students' writing at first grade of MTs Darun Rukem. The result of the study shows that the implementations of crossword puzzle 
in class VII was effectively done in improving the students' writing descriptive text.

From the previous studies above, both of them could beused as references for this research because those research had relevant study result. Both previous studies showed the same result with this study. They were using crossword puzzle and it could improve the students' writing descriptive text effectively.

\section{RESEARCH METHODOLOGY}

\section{Research Design}

The design of this research was a Classroom Action Research. According to Harmer (2007) the name given to a series procedures teachers can engage in, because they wish to improve aspects of their teaching and wish to evaluate the success and/ or appropriacy of certain activities and procedures. Moreover, Akbar (2008:26) explained that classroom action research is a process of controlled investigation to find and solve problems of teaching learning in a class, problem-solving process is done cyclical with the aim to improve the quality of learning outcomes in a particular class.

This research was focused on a certain classroom. It was designed to overcome a classroom problem in learning descriptive text has found by the researcher in practice dealing with teaching writing. In its implementation, the researcher was conducted to the class VIII students at Smp Negeri 5 Pasuruan.

\section{Research Setting and Subject}

This classroom action research was conducted at SMP Negeri 5 Pasuruan. It is located on Trunojoyo street number 291, Pasuruan.

For the research subject, the researcher chose the second grade students class F at SMP Negeri 5 Pasuruan in academic year 2016/2017. There are 30 students of class VIII $F$ which consist of 14 female and 16 male. English is taugh 2x40 minutes per meeting, twice in a week.

\section{Research Instrument}

In this research, the researcher used observation, interview, questionnaire, documentation, and test as the research instrument.

\section{Observation}

According to Ratnasari (2009), observation is an activity of consisting of receiving knowledge of the outside world through the 
senses, or the recording of data using scientific instruments. The researcher applied the observation in this study to get data in order to improve vocabulary the students' writing skill in descriptive text by using crossword puzzle. The researcher gather the data from the students involvement during the teaching learning process. The collaborator observed the implementation of the technique, the lesson plan, and the media. To help collaborator's work, the researcher provided an observation sheet in checklist form. The observation sheet consists two items of activity. First, students fill out the given puzzles and the second they create or write descriptions of the objects they get form the puzzle. The students pay attention to the teacher's explanation. Second, the students is active to ask and answer to the teacher. Third, the students is able to finish the group's well. Fourth, the students can make crossword puzzle and write descriptive text based on their puzzle. Fifth, the students can do their writing test individually.

\section{Interview}

The purpose of having interview with the teacher was to get the data dealing with the difficulties that the teacher has and also to check the general condition of the students. The researcher gave the interview sheet to the English teacher of VIII-F to get information about general condition expecially in writing class. (Appendix II)

\section{Documentation}

In this research, the researcher collected data from the lesson plan, observation checklist, students score, students' attendence list, puzzle, questionnaire, and picture of teaching learning activities in the classroom.

Test

Writing test was used by the researcher to measure the students' improvement in writing descriptive text by using crossword puzzle. The researcher conducted writing test at the end of the cycle.

The researcher used writing test to measure the students' improvement in writing descriptive text by using puzzle. The test was made by the researcher. Here, the researcher would conducted the writing test in the end of the cycle.

The form of the test was written test. In doing the test, first, the students should fill out the puzzle based on the topic. Then students had to make descriptive text based on their puzzle. The test took in thirty minutes. 


\section{Data and Sources of data}

There were two kinds of data which is got from each instruments, namely qualitative and quantitative data. According to Zuhria (2013), qualitative data is data which is got from the person's notes to analyze the research. They were observation and interview. While quantitative data were the data which is got from the score to get accurate data in implementing the research. They were the writing test.

\section{Observation}

The data are in the form of observation checklist. Observation checklist is used to observe the students activity when the researcher implemented teaching and learning process. Observation checklist consists of 3 categories. That are students enthuasiasm, responds, and activities. The observation was done on May $5^{\text {th }} 2017$.

\section{Interview}

The data were in the form of interview guide. Interview conducted on March, 29th 2017, before the cycles to reveal the real condition in the class. In this case, the researcher did the informal interview to the English teacher. The informal interview consists of several questions that was made by the researcher. Interview to the English teacher was used to get any information about the condition of the students. The data from the informal interview to the English teacher are in the form of words and sentences.

\section{Documentation}

According to Santoso (2007), documentation is written documents, such as book, magazine, documents, rules, daily note, etc. In this activity, the researcher used documentation aims to observe the teachers instructional preparation which are made by the teacher in teaching writing of descriptive text. The researcher collected the data for documentation by using camera, paper, etc. The data collected from the English teacher of SMP Negeri 5 Pasuruan. The source data were taken on April $5^{\text {th }}, 8^{\text {th }} 2017$

\section{Test}

Test as the instrument to get the students score for writing. The test was taken in the end of cycle one, on April $8^{\text {th }} 2017$. The test was in the form of written test. The form of the test was written. In doing the test, the researcher provided crossword puzzle and the researcher asked the students to organized paragraph based on the puzzle provided 
which there was instruction to make a descriptive paragraph. The researcher conducted the test which was intended to know the students' writing skill of descriptive text by using crossword puzzle. The researcher gave the score result to the students' writing test in four categories, they are organization, vocabulary, spelling, and grammar and they have 1-4 score. The data of the test are in the form of numbers.

\section{Research Procedure}

The research started with preliminary study and analyzed the preliminary study. The data would be taken from the result of observing in teaching learning writing process. From the preliminary study, the researcher used the plan, the action, the observation and the reflection.

\section{Preliminary Study}

Preliminary study have done on March, 29th 2017, in this case the researcher observed the problems of the students in studying English by doing the interview about classroom activity and observation with the English teacher. The result of preliminary study, the researcher knew that the students at eighth grade of SMP Negeri 5 Pasuruan have some problems in studying English, especially in oral and writing. Based on the interview and observation, the students have difficulty in delivering the ideas because they have low vocabulary and grammar.

\section{Planning}

In relation to the application of action research, the reseacher made a preparation prior to the implementation of the action based on the result of the reconnaissance. At this stage, the reseacher prepared the strategy in teaching writing through descriptive text activity, designs the lesson plan, prepared the material and media, prepared the criteria of success, and prepared the test.

\section{Preparing the material and media}

In doing the research, the researcher and the collaborator prepared the materials and media, which were relevant to the topic for the eight grade students of junior high school. The materials in this research were taken from available sources and selected by the researcher. The materials which were taken are about descriptive text and some vocabulary that is related to the theme (describing people and animal)and some tenses related to its function of the descriptive text. Meanwhile, the researcher also prepared crossword puzzle game related to the theme as the media which was designed by the researcher and. 


\section{Preparing the instructional media}

In conducting the research, the researcher chose playing a crossword puzzle as a media in teaching media. Crossword puzzle consisted of many questions in many theme, they are about describing animal. The teacher showed crossword puzzle to the students and shows how to play the game. The researcher divides the students into some group and asking the students to discuss the material.

Crossword puzzles is a word puzzles that normally takes the form of a square or rectangular grid of white and shaded squares, the goal is to fill the white squares with letters forming words or phrases by solving clues which lead to the answers, in a language which is written left to right, the answer words and phrases are placed in the grid left to right and from top to bottom. These shaded squares are used to separate the words or phrases, squares in which answers begin in number order the clues are then referred to by these numbers.

\section{Designing the Lesson Plan}

The lesson plans were designed on the purpose of equipping the teacher with a guideline in implementing the strategy in teaching and learning activities. It covered the school profile, the standard of competency, the basic competency, the indicator, the learning objectives, the instructional strategy, the instructional material, the teaching and learning activities, source of learning media, and the assessment.

\section{The Test}

The reseacher used written test in order to measure the students' improvement after getting the treatment. The test made by the researcher. They have to make descriptive test based on the theme given. The researcher provided the crossword puzzle with the theme "animals" in cycle one and "people" in cycle two. In conducting the test, the researcher still applied the crossword puzzle as the guidance for the students in telling their experince. The researcher asked to the students' to write a descriptive text based on puzzle. The composition was in the form of a descriptive text which was approximately 5 words.

\section{Criteria of Success}

The researcher made the criteria of success. The researcher had target the rating of students' assignment of writing. The target score is 76 (the minimum mastery criterion (KKM in English course). If the students got 76, it was considered successful. But if the score was under 
target, they were not success, and the students should improve their writing descriptive text. So, at least $80 \%$ students in the class can get 76 or more. It meant this research were successful. But if the students got less than 76 less than $80 \%$, it meant that it was unseccesful and would be continued in the next cycle. The students' writing assignment of descriptive text results were going to be assessed by the researcher and the collaborator. They determined the students' success score.

\section{Acting}

The acting of the research was the actvities done as stated in the lesson plan. The researcher implemented the plan of each cycle which was consisted two meeting. Here the researcher used crossword puzzle to improve the students' writing.

\section{observing}

In this research, the researcher focused on the use of crossword puzzle to improve the students writing in descriptive text. The researcher observed the teaching learning process during the implementation of the lesson plan and observed the students' writing activities in every cycle which consisted of two meeting.

\section{Reflecting}

In this research, the researcher reflected the teaching learning activity using crossword puzzle with the criteria of success to see the strategy succeed or not. If the student can not meet the criteria of success, it must be continued to next cycle. The researcher also used the scoring rubric for teaching writing. The formula was used to know the score of the students who reach the standard scores and to know whether this activity is successful or not.

\section{FINDINGS}

The implementation of action research was presented by describing the activities in each cycle that include the planning, the action, the observation and the reflection.

\section{Cycle One}

The cycle one consisted two meetings with the different themes animals. Every meeting conducted in 80 minutes. There were thirty students who were attend at the first meeting on cycle one. Two students were absent at the second meeting on cycle one. The first meeting was conducted on April, $5^{\text {th }} 2017$ and the second meeting was conducted on April, $8^{\text {th }} 2017$. 


\section{Planning}

The researcher planned to prepare the teaching by choosing the material, then prepared the material, media and also the lesson plan.

First, the materials were taken from syllabus based on curriculum for the second grade of junior high school which selected by the researcher. The material was about descriptive text (describing animals). The researcher and the teacher selected the materials which were relevant to the topic for the second grade students of junior high school.

Second, the researchers also prepared the media. The researchers used crossword puzzle related to the themes in teaching writing descriptive text. The material was selected based on the syllabus

The last was lesson plan. The lesson plan was prepared by the researcher for guiding the teaching. It contained the title, subject, class, semester, competence, sub competence, instructional goal, time allocation, the teaching learning procedures and the sources

\section{Acting}

Cycle one had been done on April, $5^{\text {th }} 2017$ and April $8^{\text {th }} 2017$. The researcher devided this cycle into three activities. They were pre activity, main activity and post activity.

\section{Meeting One (April, $5^{\text {th }}$ 2017)}

In the opening activity, the researcher greeted the students, checked the students attendance, made interpersonal conversation about the material that were presented and explained about the learning objective, asked the students to be active in answer and explore the ideas/opinion and showed six sets crossword puzzle of animals to the students. The crossword puzzle were fish, rabbit, lion, camel, cat, and elephant. In this research, the researcher brought the crossword puzzle from home, asked the students to mention the name of those animals in English, and gave some questions to the students about animalsand they could answer well. The students could mention the name of animals and their answer were lion, dolphin, shark, turtle, horse, sea horse. After that, the researcher explained the material about descriptive text.

In main activity, the researcher asked the students to write the vocabulary about the crossword given. In this meeting, the researcher used Horse. The vocabularies were shape, skin, color, food, life. But some students were still shy to answer the questions. 
The researcher gave a descriptive text to the students. The researcher asked them to read it. Then the researcher explained about the generic structure of descriptive text. The generic structure were identification and description. The researcher asked them to check their understanding on generic structure. The students answered that the generic structure of descriptive text were identification and description. After the researcher explained the generic structure, the researcher asked the students to identify the generic structure based on the text given. The students wrote the answer. Then the teacher discussed together with the students.

After the students filled the puzzle, they wrote the descriptive text about the puzzle. It contained some vocabulary that could help them to write easily. But they could not write well because they were still shy and confused.

In the post activity, the researcher gave summary about the lesson as feedback and disccussed about the students' difficulties during the lesson. The researcher asked the students' opinion. The students answered that it were difficult and they did not know the meaning. Then the teacher helped the students to conclude the students' answer.

\section{Meeting two (April, $8^{\text {th }}$ 2017)}

Meeting two was conducted to continue the action of this research that has been done in the previous meeting. There were three phase technique, they were pre activity, main activity, and post activity. Meeting two had been done on Saturday, April 8 2017 at. 11.00 A.M 12.45 P.M. two students were absent.

In the pre-activities, the researcher greeted and checked the students attendance. The researcher asked about the materials in the previous meeting. The researcher showed six sets crossword puzzle to the students. The puzzle were fish, rabbit, lion, camel, cat, and elephant. In this research, the researcher brought the puzzle from home.

In main activities, the researcher showed the crossword puzzle which was camel. The researcher asked the students to write the vocabularies about camel in the students book. The vocabularies should be written by the students were size, color, life.

After the students wrote the vocabularies about came and think about the characteristics of the puzzle given, the researcher asked them about the characteristics of lion. The students answered the questions. 
In the closing activity, the researcher gave summary about the lesson as a feedback and disscussed about the students' difficulties in the material given. The students difficulties were the word spelling and arranging the sentences. In the last meeting of cycle one, the researcher gave questionnaires which consisted of 10 questions. The researcher gave 5 minutes to answer the questionnaire. The students collected the result of questionnaire to the researcher. Then the teacher greeted the students.

\section{Observing of Cycle One}

The researcher used observation checklist form to observe the students who were active or not during teaching and learning process. The result of observation checklist in first meeting of cycle one was $43 \%$. It means the students activeness was low or under $70 \%$ (criteria of success). In second meeting of cycle one showed that the students activeness and the students response towards the implementation of crossword puzzle was about $61 \%$. It means that there was improvement from the first meeting which is $35 \%$ to $61 \%$ in second meeting.

In this research, the researcher started 76 as the criteria of success. But the students score in writing skills were greater than or equal 76 achieved by $70 \%$ of the students had not been achieved yet. The result of the students' writing test was below:

The researcher considered that the first cycle was unsuccessful because some problems. First, many students did not know the vocabularies, so it made them failed to comprehend the paragraph well. Second, the students did not know about puzzle as a media that used because it was the first time for them.

Because of this unsatisfactory result, the researcher decided to conduct another cycle by revising the planning. The new planning was drilled on the more vocabularies. It was aimed to anticipate the problems of the students' writing test. Consequently, the researcher decided to continue this action research to second cycle with the new treatments, so students could reach the minimum of criteria.

\section{Reflecting of Cycle One}

After observing in cycle one, the researcher could formulate the students' writing test score in written test. It was not successful as the criteria of success. This result would be successful if all students got score as the standart minimum score which was 76 . There were only 6 
students $(23 \%)$ could reach the KKM. So, the researcher decided to continue on the next cycle.

To solve the problem above, the researcher decided to revise the planning. At the first, the researcher drilled the vocabularies to the students by using crossword puzzle. Secondly, the researcher gave more motivation in order to increase their confidence in writing descriptive text, so they would not be shy to write their ideas. Finally, the researcher asked the students to make dscriptive text with theme "people". It was expected that the students would be happy and very enthusiatic to make descriptive text.

\section{Cycle Two}

Based on the result in cycle one, there were some problems for the students. So, the researcher made some solutions to solve those problem such as drilling the vocabulary and giving motivation to the students.

\section{Planning}

The researcher thought that people theme was easier for the students to construct paragraph. The activities in this cycle presented followed: in the lesson plan, the researcher devided into three activities. There were pre activity, main activity, and closing activity.

\section{Acting}

Cycle two had been done on Wednesday, April 26 ${ }^{\text {th }}$ 2017. The researcher conducted this cycle into three activities those are pre activity, main activity, and closing activity.

\section{Meeting 1 Cycle 2 (April, 26 ${ }^{\text {th }}$ 2017)}

In the first meeting of cycle two, all the students attended the class. There was no students absent. The researcher opened the lesson by giving "greeting" to the students. After that the researcher checked the attendance list. And asked them about some people. This activity was done in 10 minutes.

In main activity, the researcher showed crossword puzzle to the students one by one while introducting the names of artist. Then, the students could mention the name of the artist. The students also spelled the word of the artist. 
The researcher mentioned some clues about artists in Indonesia, then asked them to repeat what researcher said. Then, one of the students answered that she is Raisa, and the answered was correct.

The next activity, the researcher asked the students to write the characteristic of people a piece of paper then, they submited their answer to the researcher. The purpose was to train the students writing skills and to evaluate the students' understanding about material given. With the researcher, students discussed the right answers by writing the answer.

The researcher asked one of the students to come forward after that researcher asked the other students to mention the characteristics of the student. The students answered then, they mentioned that she or he has white skin. One of students also mentioned that the student was short but diligent.

The teacher gave a text for the students and asked to identify the generic structure.

Teacher : "Okay students, do you remember the previous lesson?

Students : "Yes, miss. Identification and description".

Teacher : "Good. Now, I will give you a text and you should identify the generic structure. Do you understand?".

Students : "Yes, miss".

The researcher asked the students about the generic structure of descriptive text. After that the students answered that descriptive text which consisted of identification and description. And the researcher gave a text to the students and asked them to identify the generic structure.

In the closing activity, the researcher gave summary about the lesson as feedback and discussed about the students' difficulties during the lesson. The researcher asked the students' problem and the students answered that they did not have problem. Then the researcher greeted the students as the parting.

\section{Meeting Two (May, 6 ${ }^{\text {th }}$ 2017)}

Meeting two was conducted to continue the action of this research that has been done in the previous meeting. The teaching learning process in this meeting was also devided into 3 activities such as pre activity, main activity, and post activity. Meeting two were 
conducted on Saturday, May 6 $6^{\text {th }} 2017$ at 11.00 A.M - 12.45 P.M. Two students were absent.

In the pre activity the researcher greeted and checked the students attendance. The researcher asked about the materials in the previous meeting. The researcher showed crossword puzzle to students. In this research, the researcher brought the crossword puzzle from home.

In main activity, the researcher gave a brief explanation about describing people. The researcher asked the students to answer the blank question based on the text given. The blank question was about description of Ir. Soekarno. There were ten blank questions that should be answered by the students. The purpose of the blank questions is to drill the students vocabularies and spelling.The students were drilled with several vocabularies such as L-E-A-D-E-R , C-O-U-N-T-R-Y , J-U-N-E , S-E-W , S-I-X-T-H ect. Then, with the researcher, the students disscussed the answer. Here was the conversation.

Teacher : "Okay students, kalian kan sudah belajar tentang teks deskriptif. Now. I will give you a puzzle and you must fill the blank space with the correct answers".

Students :"Yes, miss".

After the students studied about descriptive, the researcher gave the students a puzzle, then the researcher demonstrate the way to answered the puzzle. After that researcher asked the students to fill the blank space with the true answer.

The researcher asked the students to identify the characteristic of crossword puzzle given (Ir. Soekarno). Then, the students discussed together with the researcher the answers.

The researcher gave a test for the students to make a description about Ir. Soekarno based on the characteristic that they had mention. The researcher gave 25 minutes to finish their test.

In the closing activity, the researcher gave summary about the lesson as a feedback and discussed about the students' difficulties in the material given. The researcher asked to the students whether they liked learning writing in English by using crossword puzzle. The students answered that they liked it. In the last meeting of cycle two, the researcher gave a questionnaire which consist of 5 questions. The researcher gave 5 minutes to answer the questionnaire. The students 
collected the result of questionnaire to the researcher. Then the researcher greeted the students.

\section{Observing Cycle Two}

During the action in the cycle two, the researcher paid attention to what happened along the teaching learning process. It was done to know whether the students' difficulties in improving their writing skill in descriptive text. Their problem could be solved by crossword puzzle.

Comparing the result of the students' writing skills by the end od cycle one and cycle two, the researcher found that the score of the students writing skills improved. The result of the analysis indicates that the revised actions in cycle two were very useful to increase the students writing skills especially in descriptive text.

Generally the students were active during teaching learning. The revision of the media had almost fulfilled the criteria of success. In cycle two, the students' problem in spelling was better than cycle one because they drilled in spelling by the researcher and some of them brought dictionary. The students could understand the material after the researcher explained. The researcher always came to the students' seat for helping the students when they had a problem. The students were enthusiast in doin their tasks and some of them tried to write a good paragraph. They also did not depend on their friends that they always tried as their capability. Sometimes they asked to the teacher when they had a problem in doing their tasks. So, they were more confident with their task result.

The result of observation checklist in first meeting of cycle two show that $73 \%$ students were active during teaching and learning process. It means the students activeness was improved than the previous cycle. In second meeting of cycle two showed that the students activeness towards the implementation of crossword puzzle was about $88 \%$. It means the students gave good attention during teaching.

The reseracher also gave a questionnaire for the students in the of cycle two. The results showed that $82 \%$ of the students choosed "Yes" while $18 \%$ of the students choosed "No". It means that the students had positive response towards the implementation of crossword puzzle which was improved than the previous cycle. In cycle one, it showed that the students positive response was about 55,2\% but in cycle two showed that $82 \%$ of the students gave positive response towards the implementation of crossword puzzle. 


\section{Reflecting of Cycle Two}

After observing and conducting in the cycle two, the researcher compared between cycle one and cycle two. It got improvement in cycle two.

Using crossword puzzle was able to facilitate the students to improve the students' writing skills. Crossword puzzle also could help the students building idea and constructing a good paragraph. Crossword as media was needed to solve the students problem in teaching writing. It could improve the students vocabulary and was one alternatives which had been proved to provide a meaningful and memorable classroom atmosphere.

There were three students that got score under 76 . Related to the colleted data showed that $88,4 \%$ students reached the criteria of success therefore, using crossword puzzle as the media for describing people in the cycle two was more effective than before. Based on the criteria of success, the researcher was necessary to stop the research because the researcher could solve the problem.

\section{DISCUSSION}

Based on the result in cycle one, the researcher found some problems that made this research failed. First, the students still made wrong choice of vocabulary. Second, the students felt shy to write some sentences on the whiteboard. Then, the students were confused to construct a good descriptive text. It supported by Brown (2007) that the students have to pass some components of writing test required in writing. The components are content, organization, vocabulary, grammar, and mechanical. One of them is that the students' weakness in the first cycle is in vocabulary.

Not all the students could describe animals well, the result of the test at the end of the first cycle showed that 25 students got under 76 . It was not successful because it was still below criteria of success which required at least 76 as minimum score.

Based on the reflecting of cycle two, the improvement of the student's skill in writing descriptive text was shown by score obtained on the written test at the first and second cycle. In the cycle two, there were 27 students who got at least or more 76 . It can be concluded that all students got the criteria of success, which required at least 76 as the minimum score. 
Based on the result in cycle two, the researcher found some aspect that made this research successful. First, the researcher explained about new theme and also more extensive drilling vocabulary to the students.

The drilling vocabulary is good for repetition and memorization (Richard, 2001: 62). The students got more new vocabularies using Drill Technique. The researcher presented the materials for students as they needed and she should make the drill meaningful and did not over practice. According to Freeman (2011) Drill Technique helps the students more aware about punctuation and spelling. It made the students understood easily to the material then, the researcher used crossword puzzle as a media in teaching writing descriptive text. It made the students memorize the material given easily. It could be brought a good effect to the students became more confidence. It was proved by their improvement in writing descriptive text by crossword puzzle. It was supported by Ruis (2009), the teachers should apply the media in teaching learning activities because (1) Instructional media could solved the lack of the learners' experiences (2) Instructional media could reach everything out of the class (3) Instructional media are created the possible direct interaction between the learners (4) Media are produced some observation (5) Media can be kept the basic, concrete and real concept of the teaching (6) The learners' motivation are aroused by using media in learning (7) Media were integrate the experience from the concrete things to the abstract.

Based on the observation checklist in the first meeting of cycle two, the students' activeness improved $60 \%$. It was greater than in the cycle one. It means that the crossword puzzle was successful in making the students paid attention to her instruction. And in the last meeting of cycle two, the students' activeness had increased about $72 \%$. It was greater than the first meeting, so the students students could reach the criteria of success.

Here the researcher using crossword puzzle to increase the students' writing ability in descriptive text gave positive effects to the students. It was shown from result of the students' writing score from cycle one and cycle two.

In cycle one, there was $58 \%$ students active and $42 \%$ students passive in meeting one. While in meeting two there was $71 \%$ students active and $29 \%$ students passive. In the end of the cycle, the researcher gave the test to measure the students' understanding in descriptive test 
using crossword puzzle. The student got average score $69,7 \%$. It means that the researcher failure to reach criteria of success.

In the cycle two, there was $79 \%$ students active and $21 \%$ students passive in meeting one. While there was $87,5 \%$ students active and $12,5 \%$ students passive. The researcher also gave the test in the end of cycle two and the score average of the students was $75,8 \%$, the students have reached the criteria of success.

There was improvement from cycle one to cycle two. It could be concluded that crossword puzzle was suitable and it could improve the students' writing descriptive text.

\section{CONCLUSION}

Based on the findings and discussion in previous chapter, the researcher concluded that the students' writing skill in descriptive text at SMP Negeri 5 Pasuruan could be improved by using crossword puzzle. It was proven by the improvement result of the post test in the first cycle and the second cycle.

The improvement of the students' writing skill can be seen from the students activity in the class. In cycle one, the percentage of the students activity was $60 \%$ students active and $40 \%$ students passive in meeting one. While in meeting two percentage of student's activity was $72 \%$ (students active) and 28\% (students passive). In cycle two, the percentage of the students activity was $76 \%$ students active and $24 \%$ student's activity was $86 \%$ (students active) and 14\% (student's passive).

The students' score increased from cycle one to cycle two. In cycle one the percentage of students' score was $69,7 \%$. While in cycle two the percentage of student' score two was 75,8\%, it mean that the student have reached criteria of success. Therefore, the researcher did not need to continue to the next cycle. 


\section{REFERENCES}

Akbar, Sa'dun. (2008). Penelitian Tindakan Kelas. Yogyakarta: Cipta Media

Brown, H.D. (2007). Teaching by principle: An Interactive Approach to Language Pedagogy, Second Edition. New York: San Fransisco State University.

Davis Tricia, M., et al (2009), Reviewing for Exams: Do Crossword Puzzle Help in The Success of Students Learning, The Journal Of Effective Teaching, Vol. 9, No. 3, 2009, 4-10.

Dewi, N.R. (2010). The effect of Using Crossword Puzzle in Improving Students' writing descriptive text of MTs Hidayatullah Mubtdi'in Sidodadi Tempurejo Jember. Unpublished thesis. Tempurejo: Faculty of Teacher Training and Education Islamic University of Jember.

Harmer, J. (2007). The Practice of English Language Teaching (4th Ed). New York: Longman.

Nikmatul, Huda (2015). Using Crossword Puzzle Game to Improve the Students' Writing Skill in Descriptive Text At the first Grade of MTs Darun Nur Rukem Pohjentrek Pasuruan. Unpublished Sarjana Thesis. STKIP PGRI Pasuruan.

Rahmawati, H. (2013). Definition, Characteristics, and Example of Narrative, Descriptive and Expository Text, (Online), (http://hanifarahmawati.wordpress.com/2013/06/20/definit ion-characteristics-example-of-narrative-descriptive-andexpository-text), Accessed on March, 18 2014.

Ratnasari, S. (2009). Applying Autonomous Writing Instruction Model to Improve the Second Year Students' Writing Skill of SMAN 7 Malang. Malang: Unpublished Thesis. State University of Malang.

Ruis, Nuhung, Muhyidin \& Waluyo, Tri. (2009). Instructional Media. Jakarta. Ministry of Education Directorate General of Quality Improvement of Teachers and Education Personel. (Online) (http://www.uab.edu/instructionalmedia/cdm/media.htm). Accessed on April 18 2017.

Solikha, Abidatus (2014). Using Crossword Puzzle to Improve Students' Writing Descriptive Text at Seventh Grade of SMP Islam Mamba'ul Ulum Al Mubarok Jabon Sidoarjo. Unpublished Sarjana Thesis. STKIP PGRI Pasuruan. 
Suyanto, Kasihani K.E. 2008. English for Young Learners. Jakarta: Bumi Aksara.

Widaningsih, Rini. (2009). Increasing Vocabulary Mastery Using Crossword Puzzle Technique in Inclusion Program in SD Negeri Kaloran Wonogiri. Unpublished S1 thesis. Surakarta: Muhammadiyah University of Surakarta.

Zuhria, Dwi N. (2013). Improving the students writing ability on narrative text by using picture series at the first grade of SMP As-Sakdiyah Tongas Probolinggo. Unpublished S-1 Thesis. Pasuruan: English Department. STKIP PGRI Pasuruan. 